\title{
PERBANDINGAN NILAI TEKANAN DARAH, DENYUT NADI, DAN VOLUME PARU PELAKU SHALAT TAHAJUD DENGAN YANG TIDAK TAHAJUD PADA SISWA BINA SISWA SMA PLUS CISARUA, LEMBANG
}

\author{
Yuda Putra Disastra ${ }^{1}$, Reni Farenia ${ }^{2}$, A. Fauzi Yahya ${ }^{3}$ \\ ${ }^{1}$ Fakultas Kedokteran, Universitas Padjadjaran, Bandung, Indonesia, \\ ${ }^{2}$ Divisi Fisilogi, Fakultas Kedokteran, Universitas Padjadjaran, Bandung, Indonesia, \\ ${ }^{3}$ Departemen Kardiologi dan Kedokteran Vaskular, RSUP Dr. Hasan Sadikin, Bandung, Indonesia.
}

\begin{abstract}
Tahajud is qiyammul lail or sunnah muakad in Islam, which is both spiritual ans physical practice that integrating mind and body. Tahajud regularly has been showed the improvement of neuropsychoendocrinology sistem, relaxing muscle of breathing, and might be influencing cardiovasculae function. The aim of this study was to compare the effect of tahajud on blood pressure, pulse rate, and lung volume. Observational analytic study with cross-sectional design was conducted from June - October 2013, using direct measurement to compare calues of blood pressure, pulse rate, and lung volume (forced volume capacity - FVC and forced expiratory volume in 1 second) between tahajud and non-tahajud prayers. Fourty two male students at Bina Siswa SMA Plus Cisarua, Lembang included in this study as volunteer subjects after informed consent. The result are the mean difference for pulse rate $(-2,29 \pm 8,69$ vs $5,38 \pm 0,27 ; p=0,001)$, forced volume capacity $(-0,04 \pm$ $0,27$ vs 0,37 $\pm 0,27 ; p=0,012)$, systolic blood pressure $(-2(-22,30)$ vs $0(-20,30)$; $p=0,64)$, diastolic blood pressure $(0(-20,20)$ vs $0(-20,20) ; p=0,22)$, and forced expiratory volume in 1 second $(2,64 \pm 0,64$ vs $2,23 \pm 0,38 ; p=0,22)$. This study concluded that tahajud regularly provided improvement in value of cardiopulmonary system especially in pulse rate and FVC.

Keywords: blood pressure, forced volume capacity, pulse, tahajud
\end{abstract}

Korespondensi: Redaksi JIFO, Laboratorium Sentral, Universitas Padjadjaran, Jalan Raya Jatinangor KM. 21, Sumedang, Jawa Barat, Indonesia. E-mail: amrosdianto@gmail.com 


\section{PENDAHULUAN}

Salat tahajud merupakan salah satu ibadah sunnah muakad yang dicontohkan oleh Nabi dan Rasul terdahulu. Shalat tahajud dikategorikan sebagai qiyamul lail yang secara harfiah berarti berdiri di malam hari dan secara maknawiyah berarti melaksanakan ibadah pada malam hari. Dari sisi lahiriah, shalat tahajud bermanfaat untuk kesehatan karena berhubungan dengan fisik (jism). Dalam hadits diutarakan bahwa shalat tahajud memiliki banyak manfaat dan bukan hanya sekadar ibadah semata. Diilhami dari sabda Nabi Muhammad SAW, "Shalat tahajud dapat menghapus dosa, memberikan ketenangan, dan menghindarkan diri dari penyakit." (HR At-Tirmidzi). ${ }^{1} \quad$ Berdasarkan hadits tersebut, profesional telah melakukam penelitian mengenai pengaruh shalat tahajud terhadap kesehatan dan menunjukkan pengaruh yang positif., ${ }^{2,3}$

Pelaksanaan shalat tahajud menurut para ulama dikategorikan ke dalam tiga waktu pelaksanaan, yakni sepertiga malam pertama (ba'da isya pukul 00.00), dua per tiga malam pertengahan (pukul $00.00-02.30$ ), dan sepertiga malam akhir (02.30 - qabla subuh). Berdasarkan hadits, direkomendasikan untuk pelaksanaan shalat tahajud pada sepertiga malam terakhir. ${ }^{1,2}$ Hal ini berhubungan dengan circadian rhythm yakni fisiologi siklus kehidupan manusia yang berkaitan dengan sekresi kortisol yang langsung diregulasi oleh ACTH. ${ }^{4}$ Kortisol

\section{METODE}

Penelitian dilakukan pada bulan Mei - Juni 2013 di asrama Bina Siswa SMA Plus Cisarua, Lembang. Penelitian ini dilakukan dengan metode cross-sectional pada siswa laki-laki yang sudah terbiasa shalat tahajud dengan siswa laki-laki yang tidak shalat tahajud pada sekolah asrama Bina Siswa SMA Plus Cisarua, Lembang. Kriteria memiliki efek terhadap kontrol terhadap sekresi episodik dan circadian rhythm dari ACTH, rensponsif terhadap stress pada aksis hypothalamic-pituitary (HPA) dan inhibisi umpan balik oleh kortisol terhadap sekresi ACTH. ${ }^{5}$ Kortisol dapat memengaruhi fungsi jantung-paru. ${ }^{2,4,5}$

Fungsi paru juga dipengaruhi oleh lingkungan, aktivitas olahraga, nutrisi, dan gangguan pernapasan. ${ }^{3}$ Gerakan shalat yang dilakukan secara berulang dan tuma'ninah dapat dikategorikan sebagai aktivitas olahraga atau gerakan aerobik. $^{3}$ Gerakan shalat melibatkan otot-otot pernapasan, mengontrol gerak pernapasan, dan relaksasi pernapasan, serta memengaruhi tekanan darah dan denyut jantung. ${ }^{2,3}$ Pada penelitian mengenai pengaturan napas pada metode yoga, pernapasan cuping hidung / alternate nostril breathing (ANB) secara rutin dapat meningkatkan peak expiratory flow rate (PEFR) dan tekanan nadi, serta menurunkan denyut nadi (pulse rate), laju pernapasan (respiratory rate), dan tekanan darah diastolik secara signifikan. ${ }^{6}$

Belum ada penelitian mengenai pengaruh shalat tahajud terhadap fungsi kardiorespirasi. Penelitian ini bertujuan untuk melihat perbandingan nilai tekanan darah, denyut nadi, dan fungsi paru antara pelaksana shalat tahajud dengan yang tdidak melaksanakan shalat tahajud pada siswa Bina Siswa SMA Plus Cisarua, Lembang.

inklusi pada penelitian ini adalah tekanan darah <140mmHg, usia 15-17 tahun, dalam kondisi sehat, indeks massa tubuh normal, tidak merokok, serta tidak mengkonsumsi teh, kopi, dan kafein lainnya. Sedangkan kriteria eksklusi pada penelitian ini adalah memiliki riwayat penyakit jantug atau pernapasan kronis, atau sedang 
mengkonsumsi obat-obatan. Sampel minimum yang dibutuhkan dalam penelitian ini adalah 22 orang untuk masing-masing kelompok. Pengambilan sampel dilakukan secara acak.

Shalat tahajud dalam penelitian ini terdiri dari 8 rakaat ditambah dengan shalat witir 3 rakaat. Pemeriksaan tekanan darah, denyut nadi, serta volume paru menggunakan spirometer

\section{HASIL}

Dari 72 orang populasi, didapatkan 56 orang yang bersedia menjadi responden pada penelitian ini dan hanya 42 orang di antaranya yang memenuhi kriteria penelitian. Hasil pemeriksaan tekanan darah, denyut nadi, dan volume paru serta karakteristik dasar responden disajikan dalam tabel 1. Nilai dilakukan pada pukul 2.30-4.00, dan diulangi sebanyak 2 - 3 kali.

Hasil penelitian akan dianalisis menggunakan program Statistical Product and Solution Service (SPSS). Uji analisis perbandingan menggunakan uji-T tidak berpasangan jika data terdistribusi normal dan uji MannWhitney jika data tidak terdistribusi normal.

karakteristik dasar subjek berdistribusi normal kecuali tekanan darah sistolik dan diastolik.

Dilakukan uji analisis MannWhitney untuk tekanan darah dan uji-T tidak berpasangan untuk denyut nadi dan volume paru dan hasilnya disajikan dalam tabel 2, 3, dan 4.

Tabel 1. Karakteristik dasar subjek.

\begin{tabular}{lccc}
\hline Variabel & $\begin{array}{c}\text { Tahajud } \\
\text { (sampel) }\end{array}$ & $\begin{array}{c}\text { Tidak tahajud } \\
\text { (kontrol) }\end{array}$ & Nilai p \\
\hline Umur, tahun* & $16(14,17)$ & $15(14,17)$ & 0,59 \\
IMT, $\mathrm{kg} / \mathrm{m}^{2}$ (mean \pm SD) & $18,15 \pm 1,39$ & $18,89 \pm 1,33$ & 0,93 \\
Tekanan darah sistolik, mmHg* & $110(90,140)$ & $110(90,132)$ & 0,33 \\
Tekanan darah diastolik, mmHg* & $70(60,85)$ & $80(60,90)$ & 0,31 \\
Denyut nadi, beat/menit (mean \pm SD) & $68,43 \pm 4,76$ & $68 \pm 6,92$ & 0,05 \\
FVC, L (mean \pm SD) & $3,32 \pm 0,09$ & $3,36 \pm 0,11$ & 0,15 \\
FEV, L (mean \pm SD) & $2,89 \pm 0,36$ & $3,09 \pm 0,69$ & 0,25 \\
\hline
\end{tabular}

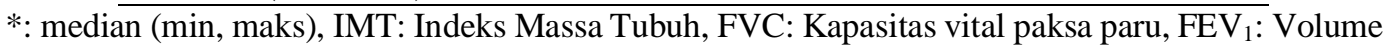
ekspirasi paksa 1 detik. Nilai p diperoleh dari hasil uji-T tidak berpasangan, Uji Mann-Whitney, atau Uji Kolmogorov Smirnov.

Tabel 2. Hasil olah data tekanan darah dengan metode Mann-Whitney.

\begin{tabular}{llccc}
\hline & Tahajud & Mean Rank & Sum of Ranks & Nilai p \\
\hline \multirow{2}{*}{ Sistolik } & Tidak & 20,86 & 438,00 & \multirow{2}{*}{0,722} \\
& Ya & 22,14 & 465,00 & \\
\hline \multirow{2}{*}{ Diastolik } & Tidak & 21,12 & 443,5 & \multirow{2}{*}{0,828} \\
& Ya & 21,88 & 459,5 & \\
\hline
\end{tabular}

Tabel 3. Hasil olah data denyut nadi dengan metode uji-T tidak berpasangan.

\begin{tabular}{lcccccc}
\hline Tahajud & n & Mean & Simpangan baku & Standard error Mean & KI 95\% & Nilai p \\
\hline Tidak & 21 & 65,71 & 6,994 & 1,526 & $-12,37$ s.d. & \multirow{2}{*}{0,001} \\
Ya & 21 & 73,81 & 6,720 & 1,446 & $-3,81$ & \\
\hline
\end{tabular}


Tabel 4. Hasil olah data volume paru dengan metode uji-T tidak berpasangan.

\begin{tabular}{lllccccc}
\hline & Tahajud & n & Mean & $\begin{array}{c}\text { Simpangan } \\
\text { baku }\end{array}$ & $\begin{array}{c}\text { Standard error } \\
\text { Mean }\end{array}$ & KI 95\% & $\begin{array}{c}\text { Nilai } \\
\text { p }\end{array}$ \\
\hline \multirow{2}{*}{ FVC } & Tidak & 21 & 2340,48 & 728,63 & 159 & $-0,578$ s.d & \multirow{2}{*}{0,012} \\
& Ya & 21 & 2358,1 & 453,29 & 98,917 & 0,180 & \\
\hline \multirow{2}{*}{$\mathrm{FEV}_{1}$} & Tidak & 21 & 3002,38 & 598,43 & 130,58 & $-0,057$ s.d. & \multirow{2}{*}{0,738} \\
& Ya & 21 & 3057,14 & 443,646 & 96,01 & 0,034 & \\
\hline
\end{tabular}

\section{PEMBAHASAN}

Dari tabel 1, seluruh subjek memiliki karakteristik yang sama rata, dengan nilai $p>0,05$. Hal ini menunjukkan bahwa tidak ada perbedaan yang signifikan pada karaktristik dasar subjek yang tahajud dengan yang tidak tahajud.

Tabel 2 menunjukkan bahwa tidak terdapat perbedaan yang bermakna antara tekanan darah sistolik dan diastolik antara subjek yang tahajud dan tidak tahajud. Hasil yang serupa didapatkan pada penelitian tentang yoga, tidak ada pengaruh yang signifikan pada tekanan darah setelah 3 bulan melakukan yoga. Akan tetapi setelah melakukan yoga selama 6 bulan, terdapat pengaruh yang signifikan. Penurunan tekanan darah ini mengindikasikan adanya aktivasi sistem saraf otonom parasimpatik. ${ }^{7}$ Melakukan yoga secara teratur dapat meningkatkan sensitivitas barorefleks dan menurunkan tonus simpatik sehingga dpaat mengembalikan tekanan darah menjadi normal pada pasien dengan hipertensi esensial. ${ }^{8}$

Tabel 3 menunjukkan $\mathrm{p}<0,05$ sehingga terdapat perbedaan rerata nilai denyut nadi yang bermakna antara subjek yang tahajud dan yang tidak tahajudm yaitu denyut nadi subjek tahajud lebih tinggi daripada yang tidak tahajud. Pada yogam ortostatis menunjukkan adanya peningkatan yang signifikan karena adanya perbaikan pada efisiensi kardiovaskuar dan kontrol homeostatik pada tubuh. ${ }^{7}$

Tabel 4, nilai $\mathrm{p}<0,05$ menunjukkan bahwa terdapat perbedaan rerata nilai FVC yang bermakna antara subjek yang tahajud dengan yang tidak tahajud, yakni nilai FVC pada subjek yang tahajud lebih tinggi daripada yang tidak tahajud. Pada analisis nilai $\mathrm{FEV}_{1}$ didapatkan nilai $\mathrm{p}>0,05$ sehingga tidak terdapat perbedaan yang signifikan antara rerata nilai $\mathrm{FEV}_{1}$ antara subjek yang tahajud dengan yang tidak tahajud.

Fungsi respirasi bergantung pada banyak faktor yang memengaruhi, termasuk sistem saraf, kekuatan otototot pernapasan, dan dimensi paru. Peningkatan pada FVC dihasilkan dari peningkatan kekuatan otot pernapasan. Tujuan utama dari paru adlaah untuk menjaga pertukaran gas dan utamanya adlaah menjaga ventilation pefusion ratio. ${ }^{9}$ Gerakan pada tahajud melibatkan otot aksesori pernapasan seperti otot interkostal internal dan eksternal, pektoralis, latisimus dorsi, erektor spina, rektus abdominis, serratus anterior, dan diafragma. ${ }^{3,9}$ Selain itu, tajwid dapat meningkatkan fungsi paru karena melibatkan pengontrolan pernapasan. ${ }^{10}$ Untuk mencegah penurunan FVC, dapat dengan melakukan latihan pernapasan dalam dan regular. ${ }^{11}$

Keterbatasan penelitian ini adalah penulis tidak dapat mengontrol semua kegiatan responden namun dapat diatasi dengan jadwal agenda rutin aseama tempat penelitian dan pengawasan dari pembina asrama yang selalu dikomunikasikan dengan penulis. Selain itu, keterbatasan waktu dan jumlah sampel yang didapatkan pada penelitian ini lebih sedikit dari jumlah sampel minimum. 


\section{PENDANAAN}

Penelitian ini tidak didanai oleh sumber hibah manapun

\section{KONFLIK KEPENTINGAN}

Tidak terdapat potensi konflik kepentingan.

\section{DAFTAR PUSTAKA}

1. El-Ma'rufie $\mathrm{S}$. Energi shalat: Bangkitkan suksesmu melalui shalat lima waktu. Ujung Berung, Bandung: Mizan Pustaka; 2009. Hlm. 191.

2. Sholeh. Terapi shalat tahajud menyembuhkan berbagai penyakit. Jakarta Selatan: Noura Books; 2012. Hlm. 259.

3. Sagiran. Mukjizat gerakan shalat. Jakarta: Qultum Media; 2011. Hlm 208.

4. Arthur C, Guyton, Hall JE. Textbook of medical physiology. Edisi ke-11: Elsevier Saunders; 2006.

5. David G, Gardner M, Dolores SM. Greenspan's basic \& clinical endocrinology. Edisi ke-8. United States of America: McGraw-Hill Companies; 2007. Hlm.958.

6. Subbalakshmi NK, Saxena SK, Urimala, Urban JAD. Immediate effect of 'Nadi Shodhana Pranayama' on some selected parameters of cardiovascular, pulmonary, and higher function of brain. Thai Journal Physiological Science. 2005; 18:10-6.

7. Indla D, Narhare P. Effect of yoga on heart rate and blood pressure and it is clinical significance.

International Journal of Biological and Medical Research. 2011;2(3):750-3.

8. Vijaya LP, Madan M, Bhavanani AB, Asmita P, Kumar BP. Modulation of stress induced by isometric hand grip test in hypertensive patients following yogic relaxation training. Indian $\mathrm{J}$ Physiol Pharmacol. 2004;48(1):5960.

9. Chanavirut R, Khaidijapho K, Jarce $\mathrm{P}$, Pongnaratorn P. Yoga exercise increase chest wall expansion ang lung volume in young healthy Thais. Thai Journal Physiological Science. 2006;19(1):1-7.

10. Putri UI. Pengaruh tilawah AlQuran terhadap fungsi paru dan tekanan darah pada peserta bimbingan baca Al-Quran Unit Kegiatan Mahasiswa belajar AlQur'an intensif Universitas Pendidikan Indonesia. Bandung: UNPAD; 2011

11. Westerdahl A, Lindmark B, Erickson T. Deep breathing exercises reduce atelectasis and improve pulmonary function after coronary artery bypass surgery. Chest. 2005;128:3482-8. 